\title{
Assessing residential building values in Spain for risk analyses - application to the landslide hazard in the Autonomous Community of Valencia
}

\author{
I. Cantarino ${ }^{1}$, F. J. Torrijo ${ }^{1}$, S. Palencia ${ }^{2}$, and E. Gielen ${ }^{2}$ \\ ${ }^{1}$ Departament of Land Engineering, Polytechnic University of Valencia, Valencia, Spain \\ ${ }^{2}$ Departament of Urban Planning, Polytechnic University of Valencia, Valencia, Spain \\ Correspondence to: I. Cantarino (icantari@trr.upv.es) \\ Received: 11 February 2014 - Published in Nat. Hazards Earth Syst. Sci. Discuss.: 22 May 2014 \\ Revised: - - Accepted: 13 October 2014 - Published: 19 November 2014
}

\begin{abstract}
This paper proposes a method of valuing the stock of residential buildings in Spain as the first step in assessing possible damage caused to them by natural hazards. For the purposes of the study we had access to the SIOSE (the Spanish Land Use and Cover Information System), a highresolution land-use model, as well as to a report on the financial valuations of this type of building throughout Spain. Using dasymetric disaggregation processes and GIS techniques we developed a geolocalized method of obtaining this information, which was the exposure variable in the general risk assessment formula. Then, with the application over a hazard map, the risk value can be easily obtained. An example of its application is given in a case study that assesses the risk of a landslide in the entire $23200 \mathrm{~km}^{2}$ of the Valencia Autonomous Community (NUT2), the results of which are analysed by municipal areas (LAU2) for the years 2005 and 2009.
\end{abstract}

\section{Introduction}

Concern for the damage caused by geo-hydrological processes such as earthquakes, floods and landslides has been on the increase in recent years at both local, regional and national levels, mainly due to the wide coverage given to the subject by the media. This concern has given rise to an increase in the number of studies focused on identifying the areas susceptible to such processes, as well as the adoption of risk management policies, and many regions have increased their budgets to mitigate the effects of natural disasters on urban areas and on their inhabitants.

One of the consequences of this movement has been the introduction by the government of measures to predict, prevent and mitigate these events. In addition, the population growth that inevitably involves a higher demand for residential buildings, together with the corresponding need for larger infrastructures, means that the population expansion spreads to areas that are often liable to suffer the effects of geo-hydrological events.

The Autonomous Community of Valencia (Spain) has adopted a firm position as regards minimizing the impact of natural or induced hazards, as reflected in Article 14 of Law 4/2004 (30 June) relating to Land Planning and Protection of the Landscape (LOTPP in Spanish), also in the decree issued on 13 January 2011 by the Council of Valencia concerning the Territorial Strategy of the Community of Valencia (ETCV). As laid down by the LOTPP, the latter is the basic land planning instrument of the Community; it fixes action plans, initiatives and guidelines for the development of the region while at the same time respecting the environment with special emphasis on natural hazards.

Among the guiding principles laid down by the ETCV is that of encouraging future urban and regional developments to take place in risk-free zones or, in cases where the risks can be justified, in minimum-risk zones. It also proposes actions to improve the management of natural and induced hazards in the form of Territorial Action Plans (PAT), including one with measures to reduce the occurrence of, and improve the management of, landslide risk. 
In the context of the above-mentioned regulations, in which adequate land planning and management are considered to be among the most important non-structural measures, there is a clear need for the creation of a risk-mapping system. These maps are an aid to regional planning as they accurately define any risk areas and compel the adoption of specific constructional measures in these zones, while at the same time they help to create legislation to regulate these activities (Palencia and Gielen, 2010).

In order to assess and compare the costs of damage caused by the different natural hazards described above, one of the basic requirements is to have access to a wide and detailed database. In addition, in order to make full use of the data it is essential to have maps showing the location of the different data (dangers, land use and occupation, etc.) to enable the application of tools and processes associated with Geographical Information Systems (GIS) for the purpose of drawing risk maps.

However, this type of map has never been fully developed for our case study (Community of Valence), mainly due to the difficulty of obtaining information on the elements they contain. Of the few that exist, most are restricted to the susceptibility to hazards and mainly analyse the characteristics of the process without paying too much attention to the possible damage to the elements exposed to the hazards (Corominas et al., 1998). However, they can be useful for purposes of land planning and mitigating hazards, as well as for reducing any possible future damage to the minimum.

As regards the European perspective, both the European Environmental Agency (EEA) and the European Territorial Cooperation Programmes (ESPON: European Observation Network, Territorial Development and Cohesion) have drawn up natural hazard maps. The EEA (2010) has compiled an exhaustive list of different types of hazards and technological accident risks of places for which maps were subsequently made. One of the reports issued by ESPON (2006) analysed the hazards and risks but did not estimate the damage in financial terms, producing qualitative scale maps at the provincial level (NUT3).

Further, some European FP7 research projects deal with similar objectives. It is worth highlighting the SafeLand project, in which a generic quantitative risk assessment, management tools and strategies for landslides are developed. Another research project is the MOVE, which creates knowledge, frameworks and methods for the assessment of vulnerability to natural hazards. These projects propose several guidelines for assessing risks and mapping, and analyse practice in local cases. Some of these guidelines have been useful for the writing of this paper.

This paper deals with risk-mapping with regard only to the damage caused to buildings, as will be explained in Sect. 2 . The proposed method of estimating the value of residential buildings is offered as the first step in assessing the risk associated with processes of any other type. As an example of its use, the method is then applied to a complete procedure for assessing the risk of landslides within the Valencia Community (NUT2, Autonomous Community) at the end of this paper.

\section{Natural hazards and risks}

\subsection{Terminology}

In general terms, risks can be defined as the interaction that takes place between the threat or danger, the elements exposed to them (people, buildings, etc.) and the severity of the damage these objects may sustain. Risk assessment is normally divided into three phases:

a. Analysis of risk factors such as hazards, exposure and vulnerability.

b. Risk assessment by calculating or estimating probable losses, usually in financial units.

c. The analysis and design of risk mitigation measures.

This paper deals with the first two phases, leaving the design and adoption of damage mitigation measures to the land planners. Our main objective is to arrive at a quantitative evaluation of risks, i.e. one that has been calculated from quantitative values of the above risk factors by the wellknown general risk equation, based on the classic definitions of the Office of the United Nations Disaster Relief Organization (UNDRO, 1979):

Risk $=$ Hazard $\cdot$ Exposure $\cdot$ Vulnerability

- HAZARD: A dangerous phenomenon, substance, human activity or condition that may cause loss of life, injury or other health impacts, property damage, loss of livelihoods and services, social and economic disruption, or environmental damage. In technical settings, hazards are described quantitatively by the likely frequency of occurrence of different intensities for different areas, as determined from historical data or scientific analysis (UN-ISDR, 2009).

- ELEMENTS AT RISK: The population, buildings and engineering works, economic activities, public services utilities, other infrastructures and environmental values in the area potentially affected by the landslide hazard (Fell et al., 2008).

- EXPOSURE: People, property, systems, or other elements present in hazard zones that are thereby subject to potential losses (UN-ISDR, 2009). Therefore, exposure indicates the extent to which the elements at risk are actually located in the path of a particular landslide (Corominas et al., 2014). 
- VULNERABILITY: The degree of loss to a given element or set of elements within the area affected by the landslide hazard. It is expressed on a scale of 0 (no loss) to 1 (total loss). For property, the loss will be the value of the damage relative to the value of the property; for persons, it will be the probability that a particular life (the element at risk) will be lost, given that the person(s) is affected by the landslide (Fell et al., 2008).

\subsection{Methodology applied for risk assessment}

In this paper, we apply the risk assessment to landslides, natural geomorphic process occurring at locations characterized by specific environment conditions. Our principal goal is mapping the risk value in a wide given area by application of Eq. (1) and by using techniques based on GIS software. In this case, the main problem is finding homogeneous data for across the chosen area - it would be interesting to explore this approach, but there are few quantitative maps on risk landslide in Spain (Bonachea, 2006). A flow diagram of the process methodology is shown in Fig. 2 (Sect. 4.4).

In the first place, to estimate hazard we start from a landslide vectorial map formed by a regional Government Department for our complete selected area. However, this map only gives some estimation of the real value of the landslide probability occurrence. Unfortunately, no specific data of quantitative hazard exist for the entire area under study, and we have to extract all the information from this map, despite the uncertainty created.

Vulnerability is the third factor of Eq. (1), and likely, the most difficult to assess, due to the complexity and the wide range of variety of landslide processes (Glade, 2003). This element has been calculated from the data on type of building in a land cover model and the intensity of landslide, following the authors cited in Sect. 4, where this term will be fully dealt with.

Finally, exposure is, of course, somewhat difficult to put a value on - regarding the value of human lives and economic activities (the value of a person, if such a thing existed, would depend on various factors such as age, employment and wage level, etc.), not to mention the difficulty of representing these values graphically, since they are not static elements. This is why most of the studies carried out are limited to material elements (Bonachea, 2006).

In the present study only residential buildings and direct structural damage are considered as assets exposed to the landslide processes, together with the functional elements that give them a market value, ignoring all other types of elements. We can justify that selection because there is far less information available to carry out the assessment of "other constructions" than for the assessment of the housing stock. In other words, non-residential buildings are not disaggregated data with the detail of residential buildings.
Also, these "other constructions" represent only $25 \%$ of residential buildings. But, the main problem is that farming and ranching constructions - elements more affected by landslides due to their location in mountain areas - are not dealt in the FFBVA study. Therefore, we have concluded that is better to exclude these data.

Moreover, we have excluded the risk of life loss, which is not unusual, perhaps due to the intrinsic difficulty of its objective definition (Catani et al., 2005). The main Spanish landslides that took place during the last 150 years were described by Corominas et al. (2005), with the number of fatalities of 659 and about 700 injured. It is important to highlight that there were no fatalities in the region that is the subject of this paper during this period of time.

This is not a minor aspect, but it will be necessary to develop a specific methodology for assessing human loss in the absence of field information.

The impact on the other elements at risk should also be considered (infrastructures, activities, etc.), but the methodology is very different and it is difficult to incorporate into this paper.

The method applied to estimate building values is dealt with in detail in the following section and is considered to be the essential first step in assessing exposure to any type of natural hazard.

\section{Valuing residential dwellings}

As the starting point of the valuation process we used the report by Albert and Uriel (2012) carried out for the Fundación $B B V A$ (FBBVA), which contains estimates of the values of housing assets and other structures in Spain, together with their distribution around the country. The values in this report were based on detailed breakdowns of housing market value and built-up areas, and thus included the value of both buildings and ground.

With this information, an assessment of the value of a residential dwelling can be made by a disaggregation of dwelling prices in a process based on the location of the different residential areas. This type of mapping information is called dasymetric mapping and stems from the paper of Wright (1936), the most well-known early example of this development. Dasymetric mapping can be defined as a cartographic technique whereby ancillary thematic data are used to refine the geographical representation of a quantitative variable reported at coarse spatial aggregations.

In our case, the quantitative variable is the housing value, and the ancillary data are the polygons that include areas with types of buildings. Building types can be identified from land use models or from cadastral data, although the latter option involves considerably more work, due to the volume and segmentation of the data, and is normally used only in studies on a limited number of municipal areas. 
Table 1. Characteristics of the CLC and SIOSE models.

\begin{tabular}{lll}
\hline & CLC & SIOSE \\
\hline Area & Europe & Spain \\
\hline Scale & $1: 100000$ & $1: 25000$ \\
\hline $\begin{array}{l}\text { Minimum Mapping Unit } \\
\text { (MMU) }\end{array}$ & 25 ha & $\begin{array}{l}0.5 \text { ha: wetlands, beaches, riverside vegetation and sea cliffs. } \\
1 \text { ha: Urban fabrics, coastal and sheets water bodies. } \\
\text { 2 ha: Agricultural land, forests and natural zones. }\end{array}$ \\
\hline $\begin{array}{l}\text { Minimum width of } \\
\text { linear elements }\end{array}$ & $100 \mathrm{~m}$ & $15 \mathrm{~m}$ \\
\hline $\begin{array}{l}\text { Data Model } \\
\text { Hierarchic: 44 classes } \\
\text { at level 3 and 58 classes } \\
\text { at level 4. }\end{array}$ & $\begin{array}{l}\text { Object-oriented: } 40 \text { simple classes and 46 predefined composed } \\
\text { classes, attribute types not included. }\end{array}$ \\
\hline
\end{tabular}

The most similar work to estimate building values for risk assessment is made by Kleist et al. (2006) within of project "Risk Map Germany". This is done on the basis of the Corine Land Cover data set and a dasymetric mapping approach, and provides a uniform database on the reconstruction cost of potentially risk-exposed residential buildings in Germany at the community level.

Another similar study was conducted in Italy by Luino et al. (2009). In that paper, the authors develop a model for flood damage estimation based on a GIS software. Estimation of the value of buildings and contents was based on knowledge of the type of structure and its use. For this, the study area database required a layer designed to contain the information and characteristics of all buildings. The estimation of a building's unit value is based, first, on a real estate and property price database, and second, on its geographical location, usage and typology.

\subsection{Land use models: SIOSE}

As is well known, great advances have been made in the definition and presentation of land mapping in the last decade. In Spain, the two most important projects on land use are the Corine Land Cover (CLC) and the Land Use and Cover Information System of Spain (SIOSE). Both projects present very different concepts, though both were carried out under the direction of the National Geographical Institute (IGN in Spanish).

In spite of the fact that the CLC represents a great advance as the first database on land use in Europe in a prolonged period of time, its lack of resolution in certain key aspects means that information has to be sought from other sources, at least on a national scale (Valcárcel, 2011). In 2005 therefore the IGN set up the SIOSE, whose aim was to generate a land use database for the entire country on a scale of $1: 25$ 000 with reference images from the year 2005 (SIOSE2005). However, although the data on land occupation have been widely developed and published, data on land use are still being worked on.

At the present time, only data on the SIOSE2005 are available for the entire country, while SIOSE2009 is still being compiled, and an update is expected for 2014, to coincide with a new version of the CLC. The SIOSE2005 was therefore used as the database in this work. Its main technical characteristics are compared to those of the CLC in Table 1.

In the SIOSE model, each polygon is defined by a land cover that may be one of two types:

- simple coverage: uniform over the entire polygon;

- composite coverage: (found in most cases) a variety of simple or even composite coverages within a polygon.

In addition, covers can be characterized by attributes or parameters that provide further information.

Of 86 possible covers, residential buildings are included in a composite coverage known as Composite Artificial within the Mixed Urban class. The model includes the simple artificial cover Buildings, characterized by a distinguishing attribute of the series of building types used in this study, details of which can be seen in Table 2 (IGN, 2010).

\subsection{Method applied to the valuation of dwellings}

The steps involved in valuing residential dwellings in SIOSE polygons are described below. A flow diagram is given in Sect. 4.4.

\subsubsection{Disaggregation of residential dwellings}

In order to consider different land values, the FBBVA Report stratified areas into urban and rural. Municipal areas were also classified by size, province, and whether they were inland or coastal, giving a total of 451 strata or areas.

The breakdown of municipal areas in each province is therefore as follows:

- inland municipal areas of up to 2000 inhabitants; 
Table 2. Attributes of the SIOSE simple cover "Buildings".

\begin{tabular}{lcll}
\hline SIOSE building type & Attribute & Notes & Abbreviation \\
\hline Isolated building & 21 & Compact block of apartments & Isolated \\
Block of flats & 22 & In urban area, non-isolated & Block \\
Single-family detached home & 23 & Single family dwelling & Detached \\
Terraced house & 24 & Houses in rows. Includes semi-detached houses & Terraced \\
Factory or warehouse & 25 & Non-residential & - \\
Under construction & 28 & Not occupied & - \\
\hline
\end{tabular}

Table 3. Summary of SIOSE building and surface types for Spain.

\begin{tabular}{lrrrrrrrr}
\hline $\begin{array}{l}\text { SIOSE } \\
\text { Building type }\end{array}$ & $\begin{array}{r}\text { No. of } \\
\text { polygons }\end{array}$ & $\%$ & $\begin{array}{r}\text { Stot } \\
\text { (ha) }\end{array}$ & $\begin{array}{c}\text { Stot(m) } \\
\text { (ha) }\end{array}$ & $\begin{array}{r}\text { Sbu } \\
\text { (ha) }\end{array}$ & $\begin{array}{c}\text { Sbu(m) } \\
\text { (ha) }\end{array}$ \\
\hline Isolated (21) & 7732 & 4.6 & 40683.3 & 3.7 & 5.3 & 13871.1 & 4.0 & 1.8 \\
Blocks (22) & 27562 & 16.3 & 166189.8 & 15.1 & 6.0 & 92734.5 & 27.1 & 3.4 \\
Detached (23) & 108035 & 63.9 & 707000.7 & 64.2 & 6.5 & 151513.9 & 44.2 & 1.4 \\
Terraced (24) & 25871 & 15.3 & 187811.5 & 17.0 & 7.3 & 84380.9 & 24.6 & 3.3 \\
\hline Total & 169200 & & 1101685.3 & & 342500.4 & & \\
\hline
\end{tabular}

Stot: total polygon surface area; $\operatorname{Stot}(\mathrm{m})$ : mean polygon surface area; Sbu: total built-up surface area; $\operatorname{Sbu}(\mathrm{m})$ : mean built-up polygon surface area.

- inland municipal areas of between 2000 and 5000 inhabitants;

- inland municipal areas of between 5000 and 10000 inhabitants;

- inland municipal areas of between 10000 and 25000 inhabitants;

- coastal municipal areas of less than 25000 inhabitants;

- municipal areas with more than 25000 inhabitants.

To georeference the values given in the tables of the FBBVA report, a dasymetric disaggregation was carried out in accordance with the definition of residential buildings in the SIOSE land use data model. The different types of building as defined by the model's attributes for Buildings cover are given in Table 2.

For each stratum in the FBBVA Report we can thus obtain the built-up surface for each of the SIOSE building types, such as $\operatorname{Sbu}(i)$. It is important to remember, for a given polygon, that this area does not necessarily coincide with the surface area of the polygon that defines it (see Table 3), since it may be composed of compound cover. According to the SIOSE, a polygon may contain various types of cover with their corresponding percentage of occupation. Built-up surface is calculated according to the ratio between this percentage and the total surface area.

The distribution of residential buildings in the whole of Spain in accordance with the four building types defined by SIOSE can be seen in Table 3 .
It is interesting to note the large area occupied by detached single-family dwellings, which is due to the different types included in this category (e.g. villas, country houses), while the others are more specific. On the provincial level, these dwellings are widely dispersed. In some coastal provinces single-family dwellings form a large majority.

The polygons containing isolated buildings are the smallest (see column "Stot"), unlike their built-up area, which is taken up by detached single-family types (see "Sbu"), these naturally occupy larger areas. However, the terraced houses, due to their better layout, occupy the largest sites (Stot), although their built-up area is equal to that of blocks of flats, though both are similarly constructed.

\subsubsection{Estimating the number of floors in each type of building}

After obtaining information on the built-up area, the next step is to estimate its gross floor area, named the equivalent dwelling surface area (Sed) for each SIOSE building type, which will mainly depend on the average number of floors above ground, and which logically must be characteristic of each building type. This will make it possible to equate total dwelling surface area to a single localized value in SIOSE with the value of the residential dwellings in the FBBVA Report, to finish off the dasymetric process.

Unfortunately, the SIOSE does not provide any information on the number of floors in each type of building. The only way to obtain these data is indirectly from the census information available on the numbers of buildings and their floors from the web page of the National Statistics In- 
Table 4. Number of floors in residential buildings in Spain according to data from the INE 2001.

\begin{tabular}{lrrrr}
\hline $\begin{array}{l}\text { No. of } \\
\text { floors } \\
(\mathrm{NF})\end{array}$ & $\begin{array}{r}\text { No. of } \\
\text { detached } \\
\text { houses }\end{array}$ & $\begin{array}{r}\text { Percentage } \\
\text { accumulated } \\
(\%)\end{array}$ & $\begin{array}{r}\text { Remainder of } \\
\text { residential } \\
\text { buildings }\end{array}$ & $\begin{array}{r}\text { Percentage } \\
\text { accumulated } \\
(\%)\end{array}$ \\
\hline 1 & 3264826 & 48.86 & 254857 & 13.20 \\
2 & 3033813 & 94.25 & 601473 & 44.35 \\
3 & 375321 & 99.87 & 327932 & 61.33 \\
4 & 5442 & 99.95 & 251742 & 74.37 \\
5 & 2104 & 99.98 & 211503 & 85.33 \\
6 & 1085 & 100.00 & 116607 & 91.37 \\
7 & 0 & 100.00 & 58652 & 94.40 \\
8 & 0 & 100.00 & 60241 & 97.52 \\
9 & 0 & 100.00 & 10109 & 98.05 \\
12 & 0 & 100.00 & 37709 & 100.00 \\
\hline Total & 6682591 & \multicolumn{3}{c}{1930825} \\
\hline
\end{tabular}

stitute (INE). The number of above-ground floors for buildings devoted mainly to dwellings can be obtained from the 2001 INE census, which makes a distinction only between single-family dwellings and other types of residential buildings (multi-family). According to the SIOSE disaggregation, these would consist of isolated buildings, blocks of flats and terraced houses, which means that the SIOSE type of detached house can easily be identified and then the typical number of floors from the INE census applied.

Although there is a time difference between the 2001 census and SIOSE2005, this is not significant, since there were no substantial changes in building types in Spain between these two dates. It should also be pointed out that the latest SIOSE land use data for Spain also dates from 2005, but as the construction rate since that time has slowed down considerably, more up-to-date statistics would not significantly affect these results.

The built-up area in SIOSE can be expected to be in direct proportion to the number of buildings per type of dwelling, i.e. to equate the number of buildings with the built-up area we must assume similar surface areas in each of the four types of dwelling. For example, single-family dwellings could be either modern villas or traditional country houses, but the built-up surface can be assumed to be close to the average in both cases (see Table 4).

Thus, in the case of single-family detached houses, according to the INE information $94.25 \%$ have one or two floors. Assuming similar floor areas, to calculate the average number of floors, weights can be applied for the number of floors per building, to obtain the weighted mean number of floors $\mathrm{NF}_{\mathrm{m}}$ by applying the following formula:

$\mathrm{NF}_{\mathrm{m}}=\sum\left(\mathrm{NF}_{j} \cdot \mathrm{NB}_{j}\right) / \sum \mathrm{NP}_{j}$,

where NB is the total number of buildings with their corresponding number of floors; $\mathrm{NF}_{j}$ being this number of floors, which, according to the INE, in the case of these buildings, is between 1 and 6 . The result is 1.57 , and this is the value that can be applied to the entire SIOSE built-up surface (Sbu) to obtain the gross floor area, or the estimated surface area of dwelling (Sed) in this category:

$\mathrm{Sed}=\mathrm{Sbu} \cdot \mathrm{NF}_{m}$.

According to the SIOSE, isolated buildings make up $7.3 \%$ of the total of multi-family dwellings (calculated from the data in Table 3, column "Sbu"), while they are $8.63 \%$ (100-91.37, see Table 4) of the number of buildings with seven or more floors. In accordance with our assumption of homogeneity between the number of buildings and the surface they occupy, these seven floors could be taken as the threshold indicator of the number of floors for the SIOSE detached buildings. Calculating the weighted average height of blocks of flats by Eq. (2), an average of 8.61 floors is obtained.

It is a somewhat more complicated task to separate dwellings in blocks of flats from terraced houses. The following premises can be assumed:

- Terraced houses will always have fewer than four floors.

- Block of flats will have more than one floor (in the smaller villages this is not the case, but the numbers here are small).

- The SIOSE ratio of terraced/block of flats surface is maintained with respect to the number of buildings.

From the above premises, we can estimate solutions which optimize the difference of squares between the SIOSE surface percentages by using the MS-Excel Solver option. One of the best results is the following distribution:

- 1 floor: $100 \%$ terraced houses.

- 2 floors: $79.6 \%$ terraced houses; $20.4 \%$ blocks of flats.

- 3 floors: $32.5 \%$ terraced houses; $67.5 \%$ blocks of flats.

- 4-6 floors: $100 \%$ blocks of flats.

Applying these coefficients and Eq. (2), the mean number of floors for each SIOSE building type can be calculated (see Table 5).

The values shown here are the mean for the whole of Spain and of course vary according to the geographic location and population of the municipal area in which they are situated. The mean surface area in terraced and semi-detached houses can be said to be similar, as can be seen from the $\mathrm{Sbu}(\mathrm{m})$ in Table 3, which also shows that the plots are understandably larger for the semi-detached houses (see "Stot(m)"), as they are in more densely populated zones provided with better roads, parks, etc.

In the absence of definitive conclusions and considering population size as one of the variables with the strongest influence on the height of buildings, an analysis was carried out with INE tables that break down data on building heights 
Table 5. Summary of results per building type.

\begin{tabular}{lrrrr}
\hline $\begin{array}{l}\text { SIOSE } \\
\text { building type }\end{array}$ & $\begin{array}{r}\text { Built-up SIOSE } \\
\text { surface Sbu (ha) }\end{array}$ & $\begin{array}{r}\text { Total number of } \\
\text { buildings (INE 2001) }\end{array}$ & $\begin{array}{r}\text { Average surface } \\
\text { per building }\left(\mathrm{m}^{2}\right)\end{array}$ & $\begin{array}{r}\text { Average number of } \\
\text { floors NFm }\end{array}$ \\
\hline Isolated & 13871.14 & 166711 & 832 & 8.61 \\
Block & 92734.50 & 923690 & 1004 & 3.98 \\
Detached & 151513.85 & 6682591 & 227 & 1.57 \\
Terraced & 84380.91 & 840424 & 1004 & 1.82 \\
\hline
\end{tabular}

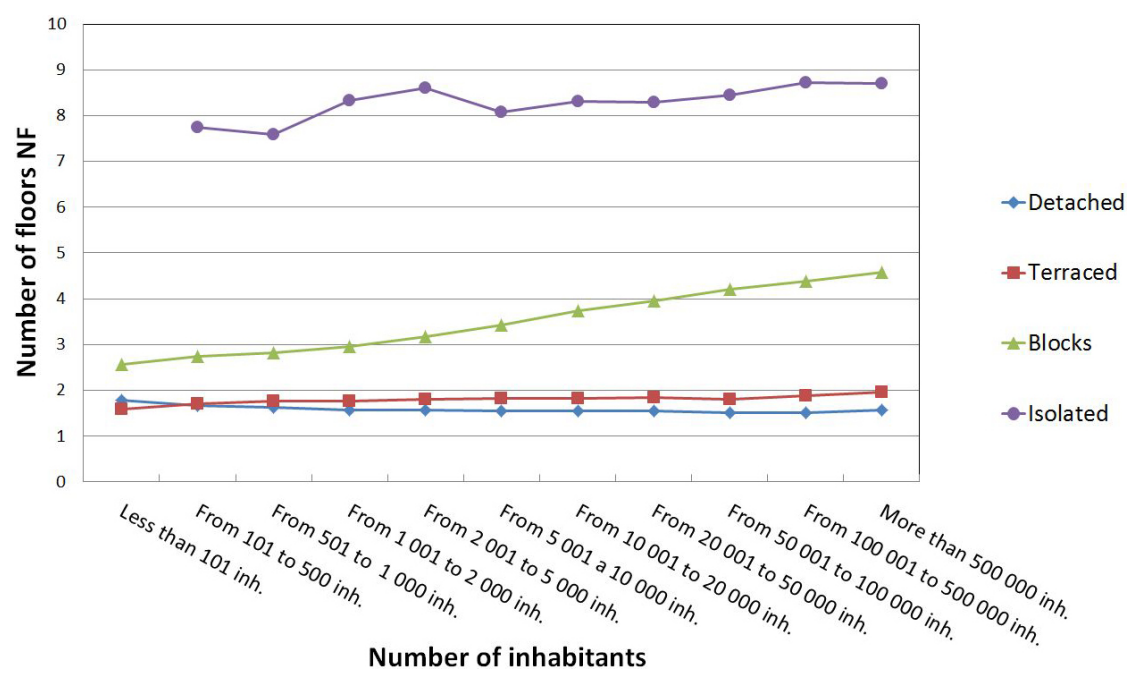

Figure 1. Variation in number of floors per type of building and municipality size.

according to municipality size into eight different population levels between less than 100 and more than 500000 inhabitants.

The results of applying the same type of distribution as the exposed coefficients for terraced/blocks buildings to each population level can be seen in Fig. 1 .

In accordance with the data from this graph, it can be concluded that:

- In isolated buildings the number of floors ranges from 7.6 to 8.7. This variance is not important, especially as it involves a limited number of buildings.

- In blocks of flats it lies between 2.5 and 4.9. The variance here is wider and due to the number of buildings involved this is where the figure should be adjusted for size of municipality.

- In detached single-family houses floors vary between 1.8 and 1.5. This is the only type of building with a tendency to decrease, although it is fairly stable in the municipal areas with higher populations.

- In terraced houses the figure is between 1.6 and 2.0, which is a not a highly significant variation.

\subsubsection{Adjusting housing value for type of building}

It should not be forgotten that when valuing a dwelling we must bear in mind not only its surface area but other specific criteria related to its type, location, use, quality, etc. We therefore gave a weighting to the calculated surface (Sed) according to these characteristics to obtain the equivalent dwelling surface (Sevd) related to its value.

The Spanish Colleges of Architects make use of formulas to calculate the Reference Building Cost (RBC) according to a Basic Module Building (BMB in $€ \mathrm{~m}^{-2}$ ). We adopted the RBC recommended by the Valencia Building Institute (IVE), an organization belonging to the Government of Valencia (IVE, 2012):

$\mathrm{RBC}=(\mathrm{BMB} \cdot \mathrm{Ct} \cdot \mathrm{Ch} \cdot \mathrm{Cu} \cdot \mathrm{Cnv} \cdot \mathrm{Cs} \cdot \mathrm{Cc}) \cdot \mathrm{Sc}$,

where RBC is Reference building cost $(€), \mathrm{BMB}$ is Basic module building $\left(€ \mathrm{~m}^{-2}\right)$, Ct is Type of building, Ch is Number of floors above ground, $\mathrm{Cu}$ is Location in historic centre, $\mathrm{Cs}$ is Useful living area (predominant size), $\mathrm{Cv}$ is Number of dwellings per unit, $\mathrm{Cc}$ is Quality of finish and $\mathrm{Sc}$ is Built-up surface $\left(\mathrm{m}^{2}\right)$.

We used the most significant and applicable coefficients, so that the surface equivalent to the value of the dwelling 
Table 6. Coefficient of increase in building's value $(\mathrm{Cg})$.

\begin{tabular}{lccccc}
\hline $\begin{array}{l}\text { SIOSE } \\
\text { building } \\
\text { type }\end{array}$ & $\mathrm{Ct}$ & $\mathrm{Ch}$ & $\mathrm{Cv}$ & $\mathrm{Cc}$ & $\mathrm{Cg}$ \\
\hline Isolated & 1.050 & 1.025 & 1.000 & 1.000 & 1.076 \\
Block & 1.000 & 1.000 & 1.000 & 1.000 & 1.000 \\
Detached & 1.150 & 0.975 & 1.100 & 1.200 & 1.480 \\
Terraced & 1.100 & 0.975 & 1.100 & 1.100 & 1.298 \\
\hline
\end{tabular}

(Sevd) could be expressed by the following formula:

$\operatorname{Sevd}=(\mathrm{Ct} \cdot \mathrm{Ch} \cdot \mathrm{Cv} \cdot \mathrm{Cc}) \cdot \mathrm{Sed}=\mathrm{Cg} \cdot \mathrm{Sed}$,

in which $\mathrm{Cg}$ is the general weighting coefficient of the value of the building per SIOSE type (see Table 6).

\subsubsection{Calculating value of SIOSE residential polygons}

According to the preceding sections, it is possible to calculate the equivalent surface of a dwelling from its Sevd value in square metres for any given polygon $p$ defined by SIOSE with a determined building type $i$, with a certain constructed surface area Sbu $\left(\mathrm{m}^{2}\right)$ together with a mean number of floors $\mathrm{NF}_{\mathrm{m}}$. This is expressed by the following equation from Eqs. (3) and (5):

$\operatorname{Sevd}(p)=\operatorname{Sbu} \cdot \mathrm{NF}_{\mathrm{m}}(i) \cdot \mathrm{Cg}(i)$.

For a given layer $e$ of the 451 defined in the report by Albert and Uriel (2012, see Sect. 3.2.1) the total surface area of dwellings Sevd, including all SIOSE building types, will be

$\operatorname{Sevd}(e)=\sum \operatorname{Sevd}(i)=\sum \operatorname{Sbu}(i) \cdot \mathrm{NF}_{\mathrm{m}}(i) \cdot \operatorname{Cg}(i)$.

With this figure, the value of dwellings per surface $\operatorname{Vds}(e)$ is calculated in $€ \mathrm{~m}^{-2}$ for each layer $e$, according to the value of total dwellings $\operatorname{Vdt}(e)$ as established by the cited FBBVA Report:

$\operatorname{Vds}(e)=\operatorname{Sevd}(e) / \operatorname{Vdt}(e)$.

It is now possible to perform a dasymetric distribution of the total value of dwellings among the different residential building polygons with the attribute $i$ as defined by SIOSE, $\operatorname{Vd}(p)$. For each polygon $p$, this value will be defined by the specific value $\operatorname{Vds}(e)$ of the layer $e$ to which it belongs and its equivalent surface area $\operatorname{Sevd}(p)$, according to

$\operatorname{Vd}(p)=\operatorname{Vds}(e) \cdot \operatorname{Sevd}(p)$.

In other words, a financial value is assigned to each SIOSE residential polygon according to the number of dwellings it contains. This information is of great interest since it forms the basis required to assess the exposure to any type of risk.

\section{Case study: assessment of landslide risk in the Community of Valencia}

We considered it to be of great interest to carry out a specific application of the proposed method of valuing dwellings to assessing a certain natural hazard within a given region. The threat selected was land movement and the region selected was the Community of Valencia (NUT2, Autonomous Communities), composed of the three provinces of Alicante, Castellón and Valencia (NUT3, Provinces) and making up $5 \%$ of the surface $\left(22200 \mathrm{~km}^{2}\right)$ and $11 \%$ of the population of Spain. The results are given by province and municipalities (LAU2, Municipalities).

Our selections were based mainly on three reasons:

- Availability of the necessary maps: landslide susceptibility in the whole of the Valencia Community (COPUT, 1998) and two versions of the SIOSE model, as this was also available for this Community in 2009. The same calculation process was therefore carried out for two years, thus giving an assessment of the evolution of risk for the period 2005-2009.

- The three provinces had been described as being areas of "high hazard" for landslides in the above-cited ESPON Report (2006), although it did not specify the areas in which they could occur.

- The need to identify the trouble spots in the territory and draw up detailed maps, proposing both structural and land planning measures. This is an explicit approach related to Objective 8 of the above-mentioned ETC risks.

Exposure was to be assessed in accordance with the process described in the next section. Still to be defined are hazard and vulnerability, which will be dealt with in the subsequent sections.

\subsection{Exposure}

Almost all authors (Varnes, 1984; UNDRO, 1991) agree as to the elements to be considered as being affected by landslides. However, each author has a distinct way of dealing with the different types of elements, as will be seen below when we consider vulnerability, as the elements exposed to risk and vulnerability are directly related to each other.

Exposure is an attribute of people, property, systems or other elements present in areas that are potentially affected by landslides. It is calculated as the temporal and spatial probability that an element at risk is within the landslide path, and it also needs to be incorporated into the risk equation (Corominas et al., 2014).

In this work we dealt only with residential buildings exposed to the landslides in accordance with the method described in the preceding section. One of the important questions was the calculation of the distribution of the number of 
Table 7. Mean number of floors per layer for block of flats.

\begin{tabular}{lc}
\hline & $\begin{array}{c}\text { Mean number } \\
\text { of floors for } \\
\text { blocks }\left(\mathrm{NF}_{\mathrm{m}}\right)\end{array}$ \\
\hline Inland municipalities up to 2000 inhab. & 3.1 \\
Inland municipalities between 2000 and 5000 inhab. & 3.4 \\
Inland municipalities between 5000 and 10000 inhab. & 3.6 \\
Inland municipalities between 10000 and 25000 inhab. & 3.7 \\
Coastal municipalities with less than 25000 inhab. & 4.0 \\
Municipalities with more than 25000 inhab.: & \\
Up to 50 000 inhab. & 4.0 \\
Up to 100000 inhab. & 4.3 \\
Up to 500 000 inhab. & 4.6 \\
> 500 000 inhab. & 5.0 \\
\hline
\end{tabular}

floors. For terraced buildings, which show the greatest variance, as can be seen in Fig. 1, a special study was carried out. As we have outlined in Sect. 3.2.2, from the population size data for the municipal areas of Valencia (from the INE Census for 2001) we obtain Table 7.

As can be seen in Fig. 1, the values of the number of floors in the remaining building types show little variation with population size and were thus assumed to be constant in all municipal areas, coinciding with the mean given in Table 5 (Sect. 3.2.2).

\subsection{Hazard}

The description of landslide hazard should include the location, volume (or area), classification and velocity of the potential landslides and any resultant detached material, and the probability of their occurrence within a given period of time (Fell et al., 2008).

For this work, spatial hazard data were taken from a $1: 50000$ scale vector format landslide map drawn up by the Regional Department of Public Works of the Valencia Government in the project entitled Lithology, exploitation of industrial rocks and landslide risk in the Valencian Community (Thematic Mapping Series, COPUT, 1998), using geological and geotechnical maps from the Spanish Geomining Technical Institute (ITGME), 1:50000 scale topographical maps from the Army Geographical Service, as well as aerial photographs available at that time. That map is a useful and required tool, since is a necessary observance for urban and territorial planning at the Community of Valencia (COPUT, 2000), according to Article 63 of the LOTTP law cited in Sect. 1.

The COPUT official map differentiates solely rock fall (835 polygons) from the rest of landslides (flows and slides, 3584 polygons). In our region, with a Mediterranean climate, not very cold and dry, the rotational or planar slides are the more common types of instability.

Now, we need to calculate the hazard with the estimation of the temporal probability of occurrence of landslides in our area, on the basis of the COPUT map. We choose to express this temporal occurrence as a frequency: number of events in a certain time interval. Also, as we are working with large area and small scales, it is appropriate to express the ratio of the number of observed landslide events to unit time (Corominas et al., 2014).

Unfortunately, in Spain there is no systematic and historic inventory of the distribution, characteristics and consequences of past landslides. The national landslide database has only 569 events on an inventory map $1: 200000$ that has not been updated. There are two regional landslide databases developed in Sierra Nevada (Andalusia, Granada) and Catalonia (Van Den Eeckhaut and Hervas, 2012). Accordingly, there are no wide official landslides records in our region, field works or remote sensing analysis.

As we need an estimation of primary level hazard, we must go to another source of data. Some authors (Glade et al., 2005; Fell et al., 2008) suggest a primary method to assess the historic frequency of landslides from basic incident databases. Thus, in our area of study, the only way to establish the landsliding temporal frequency is to consult local newspaper records, searching their internet resources, or other ancillary sources.

By this means, we have found only 10 registered landslides in the last half century, in inhabited areas. These were: Arenós (1957), Alcoy (1958), Lucena del Cid (1976), Monóvar (1987), Sueras (1987), Villahermosa (1987), Oliva (1987), Cortes de Pallás (1988), Altea (2007), El Toro (2008). Furthermore, we estimate that there were an equal number of unregistered events, at least, the majority in uninhabited areas. Thus, the average historical frequency for the Valencian Community is 0.40 events $\mathrm{yr}^{-1}$ (20/50) over this last 50-year period.

These landslides have a strongly heterogenic spatialtemporal distribution, a function of the trigger mechanisms. In our area (and nearby), frequently these mechanisms are the high-intensity, short-lasting rainfall episodes in autumn when the sea is still warm (about $100 \mathrm{~mm}$ day $^{-1}$ ). These episodes have a highly random distribution, both spatial and temporal (Corominas, 2006). For instance, the official Spanish rainfall record in $24 \mathrm{~h}$ occurred in November 1987, when $817 \mathrm{~mm}$ fell a day in Oliva (Valencia).

As we have seen, hazard is the temporal probability. In our study, we can estimate this probability by means of the historical landslide frequency. In this approach, we have not considered the bias introduced by the rainfall trigger mechanism, or other factors, and we have supposed a uniform distribution of the probability for the whole territory.

Thus, the relationship between the number of annual historical events (0.40) and the total possible landslides (3584 polygons) provides us with an estimate of the average annual probability of failure for every one of the entire population of landslides. This probability is above 0.0001 , and according to the classification of Lee and Jones (2004), landsliding is highly unlikely, but not impossible within a normal lifetime. 
Finally, for our calculations and the purposes of the quantitative hazard assessment, we fit the "risk" class values of the COPUT map in terms of probability. Thus, "low" was considered as 0.00025 , "medium" 0.00050 and "high" 0.00075 .

We cannot consider different types of mechanism due to lack of data, and we assume a homogeneous region with similar landslide behaviour. We believe this simplified methodology is enough for our first approach.

\subsection{Vulnerability}

Varnes (1984) was one of the first authors to use the term vulnerability in a review of the different aspects involved in risks due to different natural or technical phenomena. He considered vulnerability to be the degree of potential damage, expressed from 0 to 1 , sustained by an exposed element or group of elements as a result of a natural phenomenon of a given intensity. This definition has been almost universally accepted by later researchers in the field of landslides, most of whom refer to the cited work (Brabb, 1984; Alexander, 1993; Fell, 1994; Leone et al., 1996b; Leroi, 1996; IUGS, 1997; Dai et al., 2002).

However, the intensity of a landslide is somewhat difficult to quantify in practice, since it depends largely on the nature and the intensity of the mechanical forces generated by the landslide (differential movements in the terrain, subsidence, thrusting force, load, specific weight, depth, etc.) and the vulnerability characteristics of the exposed elements (Leone et al., 1996a). It is also difficult to separate vulnerability from hazard and risk, since these concepts are intimately interrelated in a complex way (Alexander, 2000).

It is therefore difficult to design a standard and complete method of assessing vulnerability. According to Bonachea (2006) in a review of the problem, few studies have been published to date on the subject, and most of them use highly subjective methods that are impossible to reproduce or are only applicable to specific zones.

At present, there is an ongoing debate regarding the definition of vulnerability. Scientists with various scientific backgrounds have a different understanding of what vulnerability is (Glade, 2003). In a recent review of existing vulnerability assessment methodologies for Alpine hazards (landslides, rock falls, debris flows, and snow avalanches), PapathomaKöhle et al. (2011) suggest that there is neither a common definition for vulnerability nor a standard methodology for vulnerability assessment. This author recorded a range of methodologies by reviewing 41 vulnerability assessment methodologies for alpine hazards. Most of them took into consideration only one vulnerability indicator which was mostly the building type. Scientists often develop vulnerability curves - in other words, functions that express the relationship between the degree of loss and the intensity of the process. One recent example of this research can be seen in Papathoma-Köhle et al. (2012).
There are several methodologies used for the quantification of vulnerability according to the type of input data and the evaluation of the response parameters (Corominas et al., 2014). The data-driven methods are frequently used and they offer both simplicity and reliability, although they also introduce a degree of subjectivity.

Our cited lack of inventory data makes it necessary to obtain empirical index based on other authors (Leone et al., 1996), that increases the subjectivity - but we can obtain a representative vulnerability. In a recent work on a regional scale for buildings and people as exposed elements, $\mathrm{Li}$ et al. (2010) define Vulnerability as a function of intensity and resistance to scenario-based landslide hazards. According to Li et al., Vulnerability $(V)$ is a function of the hazard intensity $(I)$ associated with exposed elements at risk and the resistance ability $(R)$ of the elements to withstand a threat $(R)$ : thus $V=f(I, R)$. Therefore, the vulnerability is calculated for each of the 3584 spatially distributed landslide polygons. This theoretical approach is the only way to assess the vulnerability, because we have no historic data or loss estimation models in our region. In fact, this problem is usually one of the largest obstacles in land risk assessment (Van Westen et al., 2005).

For a landslide, the magnitude can be defined with several parameters including volume, velocity, depth, run-out, and area extent (Lee and Jones, 2004; Fell et al., 2005; Li et al., 2010). It is considered that for a landslide event, we have one magnitude value but infinite intensity values. Intensity can be expressed in terms of either a dynamic or geometric factor. We have no data in our catalogue for evaluating the dynamic factor. We suppose that, with similar landslide mechanisms, the depth and velocity can be assumed virtually as a constant. Thus, the intensity is a function of the geometric factor, and can be set proportional to the area of the mapped landslide (Catani et al., 2005).

In Table 9, the intensity is set in three levels, percentiles defined:

- Intensity 1 (Low): Landslide area $<21.3$ ha

- Intensity 2 (Medium): Landslide area 21.3-56.1 ha

- Intensity 3 (High): Landslide area > 56.1 ha.

As regards the sensitivity of buildings to landslides, we use the four types of buildings cited by the SIOSE classification. Although no specific data are available on their characteristics, information is obtainable pertaining to their building types, number of floors and whether detached or nondetached, which can be equated with one of the four types proposed by Leone et al. (1996a, p. 142), between B1 (highly vulnerable) and B4 (least vulnerable), see Table 8. It is now possible to carry out a classification similar to that proposed by Leone et al. (1996a, 140-141) with structural damage matrices that consider landslide intensity and the characteristics of the asset exposed to hazard. Table 9 gives the results of 


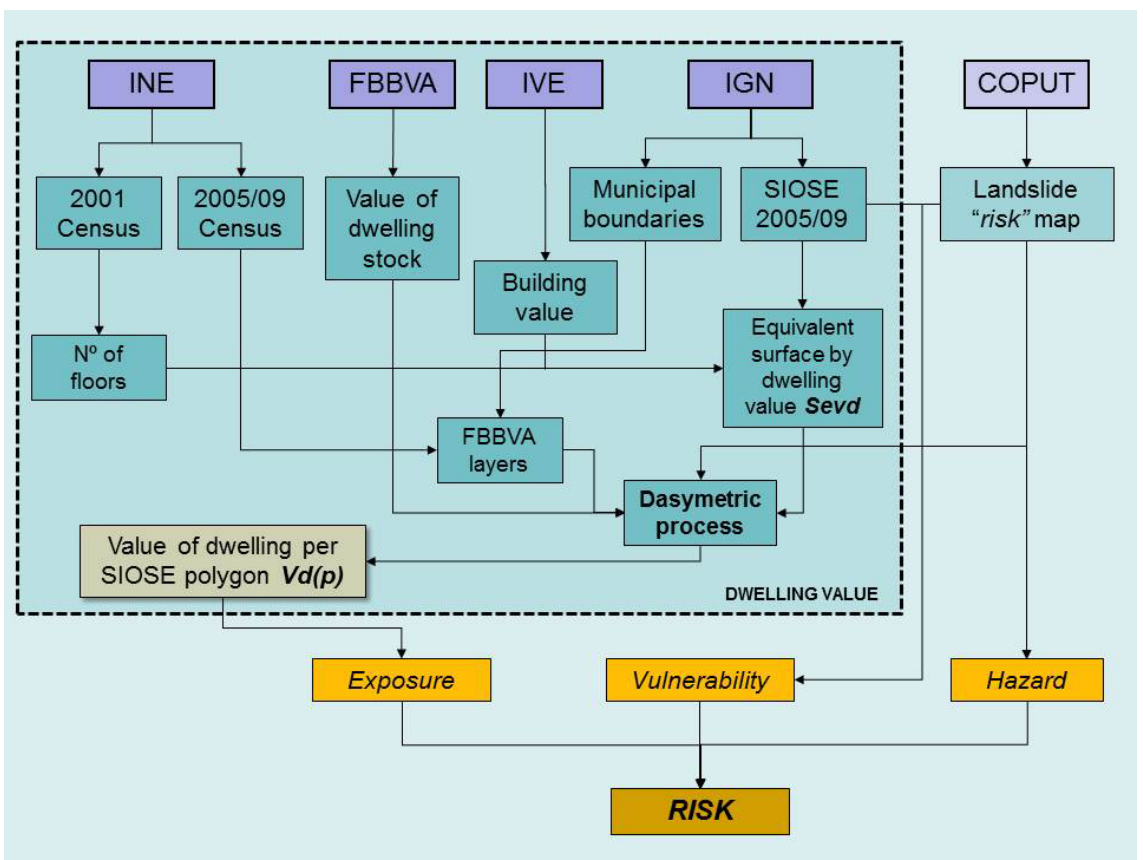

Figure 2. Flow diagram. INE: Spanish National Statistics Institute; FBBVA: Foundation of the BBVA bank; IVE: Building Institute of Valencia (Valencia Government); IGN: Spanish National Geographical Institute; COPUT: Department of Public Works, Town Planning and Transport: Valencia Government.

Table 8. Assigning building types according to Leone et al. (1996a).

\begin{tabular}{lll}
\hline $\begin{array}{l}\text { SIOSE } \\
\text { building } \\
\text { type }\end{array}$ & Characteristics & $\begin{array}{l}\text { Leone } \\
\text { type } \\
(1996 \mathrm{a})\end{array}$ \\
\hline Isolated & $\begin{array}{l}\text { Good quality construction, } \\
\mathrm{NF}_{m}=8, \text { modern, detached. }\end{array}$ & $\mathrm{B} 3, \mathrm{~B} 4$ \\
\hline Block & $\begin{array}{l}\text { Widely variations in quality and age. } \\
\mathrm{NF}_{m}=4 . \text { Non-detached. }\end{array}$ & $\mathrm{B} 2$ \\
\hline Detached & $\begin{array}{l}\text { Generally good structural quality, } \\
\text { age variable. NF }\end{array}$ & $\mathrm{B} 3$ \\
\hline Terraced & $\begin{array}{l}\text { Good structural quality. } \mathrm{NF}_{m}=2 . \\
\text { Modern. Non-detached. }\end{array}$ & $\mathrm{B} 4$ \\
\hline
\end{tabular}

the final vulnerability assessment by a simplified method according to intensity and building type. This author classifies damage according to a certain vulnerability interval, included as a reference.

The damage levels are really the factors that determine vulnerability and the numerical values are an indication of the loss of value of a building after suffering the effects of a landslide. In our case, these numerical values were difficult to calculate directly as there were no databases available of the market value of affected buildings.
Table 9. Assessment of vulnerability according to type of building and landslide intensity. Damage estimates according to Leone et al.'s associated interval (1996a).

\begin{tabular}{|c|c|c|c|c|c|c|}
\hline \multirow{2}{*}{\multicolumn{2}{|c|}{ Intensity }} & \multicolumn{4}{|c|}{ Building type } & \multirow{2}{*}{ Structural damage } \\
\hline & & 22 & 23 & 21 & 24 & \\
\hline 1 & Low & 0.35 & 0.30 & 0.25 & 0.20 & $\begin{array}{l}\text { Cracks in walls that do not } \\
\text { affect stability. Repairs not } \\
\text { urgent. }[0.20-0.30]\end{array}$ \\
\hline 2 & Medium & 0.55 & 0.50 & 0.45 & 0.40 & $\begin{array}{l}\text { Marked deformations, large } \\
\text { breaches in walls, cracks in } \\
\text { supporting structures, stability } \\
\text { affected, evacuation necessary. } \\
{[0.40-0.60]}\end{array}$ \\
\hline 3 & High & 0.85 & 0.80 & 0.75 & 0.70 & $\begin{array}{l}\text { Structural damage, partially } \\
\text { destroyed, evacuation } \\
\text { inevitable, reconstruction of } \\
\text { affected parts. }[0.70-0.80]\end{array}$ \\
\hline
\end{tabular}

\subsection{Assessing risk}

After defining exposure, hazard and vulnerability, all the elements to assess the risk according to the Eq. (1) are available. The assessment was performed using ESRI ArcGIS 10.1 software, automated by routines written in Python with an ArcPy geoprocessor.

Figure 2 shows the flow diagram of the process. In the final step the risk values were divided into administrative units in order to carry out a provincial (NUTS3) and municipal (LAU2) analysis (see Sect. 4.5). 
Table 10. Surface area of affected dwellings and total risk according to hazard.

\begin{tabular}{l|cr|rr}
\hline Hazard & $\begin{array}{c}\text { Surface area of } \\
\text { affected dwellings } \\
\text { Sed }\left(\mathrm{km}^{2}\right)\end{array}$ & \multicolumn{2}{|c}{$\begin{array}{c}\text { Total risk } \\
(€ \text { thousand })\end{array}$} \\
\hline & 2005 & 2009 & 2005 & 2009 \\
\cline { 2 - 5 } Low & 20.1 & 20.7 & 351 & 415 \\
Medium & 18.8 & 19.7 & 971 & 1189 \\
High & 5.6 & 5.7 & 471 & 628 \\
\hline Total & 44.5 & 46.1 & 1793 & 2232 \\
\hline
\end{tabular}

\subsection{Results}

As the SIOSE land use data are available for 2005 and 2009, partial and complete calculations were carried out for these years on all areas subjected to landslide hazards according to the COPUT maps. The hazard values are shown in Table 10, in which it can be seen that the estimated surface area covered by dwellings (Sed) under high risk is relatively small (around $12 \%$ for both years), although their incidence on risk values is more than one quarter ( 26 and $28 \%$ ). The greatest hazard and vulnerability of these areas justify these results and highlight the need to act on them.

Total risk increased by almost $25 \%$ (439000 $€$ ) between the years 2005 and 2009, even though Table 10 shows that the dwelling area (Sed) is practically the same. The analysis of this table makes it clear that the increased risk is not due to increased construction levels in the high risk zones during the study period, but to the higher values of the dwellings, since the values of the exposed elements increased much more than the residential surface area affected. It is worth remembering at this point that 2009 marked the end of the housing boom in Spain in which housing prices moved continually upwards.

Regarding the provincial values as given in Table 11, it can be clearly seen that Alicante is the province most affected by total risk, with more than one million euros in both 2005 and 2009. This is chiefly due to the coastal zones in the northwest of the province (Marina Alta and Marina Baixa areas; see Fig. 3), with a high demand for housing, being hilly regions susceptible to higher landslide risks.

The Valencia Community is divided into 542 municipalities, more than half of which (268) are affected to a greater or lesser degree by risk of landslides (see Table 12). The risk-assessment ranges adopted coincide with the percentiles $20-40-60-80$ for the total data, with limits of $2500-55000$ 102900 euros, respectively.

Furthermore, the group or layer of municipalities with the highest risk is that with less than 25000 inhabitants in the coastal regions of Alicante. Finally, 23 municipalities were found to have between 90 and $100 \%$ of their dwelling surface area exposed to risk of a landslide.

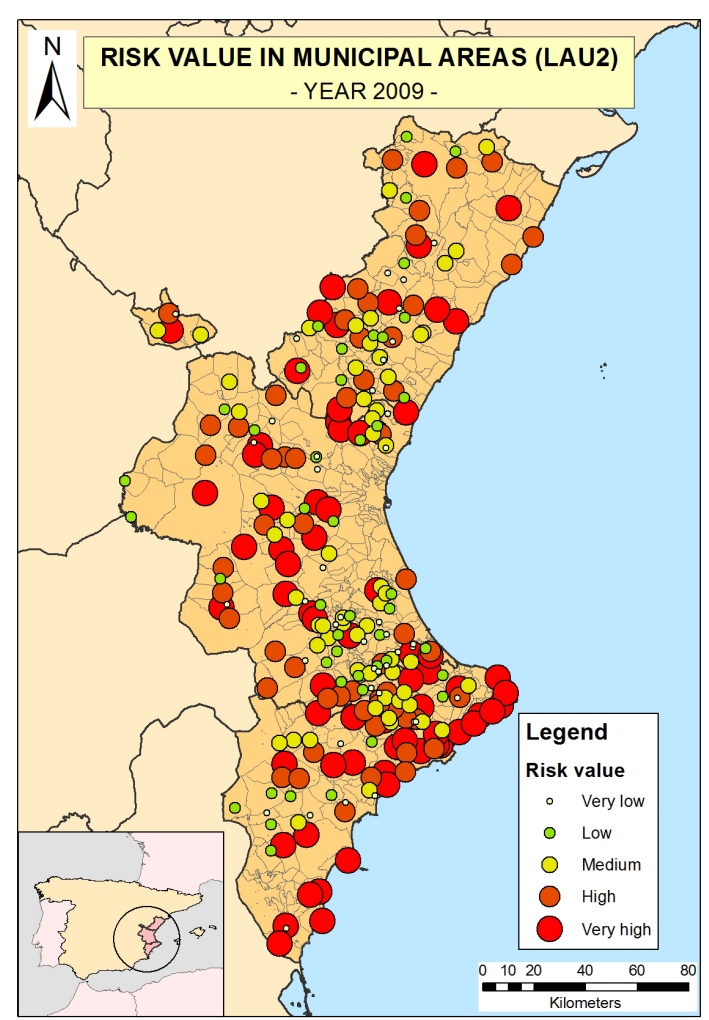

Figure 3. Location and quantification of risk value by municipality in the Valencia Community.

Table 11. Surface area covered by dwellings, exposed elements and risk by province.

\begin{tabular}{l|rr|rr|rr}
\hline & $\begin{array}{c}\text { Surface area of } \\
\text { affected dwellings } \\
\text { Sed }\left(\mathrm{km}^{2}\right)\end{array}$ & $\begin{array}{c}\text { Exposed elements } \\
(€ \text { thousand })\end{array}$ & \multicolumn{2}{|c}{$\begin{array}{c}\text { Total risk } \\
(€ \text { thousand })\end{array}$} \\
\hline & 2005 & 2009 & 2005 & 2009 & 2005 & 2009 \\
\cline { 2 - 8 } Alicante & 23.6 & 24.3 & 5966 & 6569 & 1088 & 1216 \\
Castellón & 6.6 & 7.1 & 1171 & 1753 & 236 & 352 \\
Valencia & 14.3 & 14.7 & 2044 & 2862 & 469 & 664 \\
\hline Total & 44.5 & 46.1 & 9181 & 11184 & 1793 & 2232 \\
\hline
\end{tabular}

Figure 3 shows the map of the results by municipalities and risk level for the entire Valencia Community for the year 2009.

\section{Discussion}

The application of the above methodology has achieved results at the provincial and municipal levels for the whole Valencian Community for two dates. Analysing the results, they seem entirely consistent with the knowledge we have of Valencia on land use, hazard and property market. The knowledge of the area in terms of land use and hazard can explain the results for each one of the areas (provinces, municipali- 
Table 12. Risk ranges by municipality (thousands of euros).

\begin{tabular}{|c|c|c|c|c|c|}
\hline \multirow{2}{*}{ Province (NUT3) } & \multirow{2}{*}{ Risk range } & \multicolumn{2}{|c|}{2005} & \multicolumn{2}{|c|}{2009} \\
\hline & & No. LAU2 & Risk $\left(10^{3} €\right)$ & No. LAU2 & Risk $\left(10^{3} €\right)$ \\
\hline \multirow{5}{*}{ Alicante } & 1 & 12 & 1 & 11 & 1 \\
\hline & 2 & 9 & 7 & 10 & 8 \\
\hline & 3 & 18 & 42 & 16 & 37 \\
\hline & 4 & 20 & 125 & 20 & 116 \\
\hline & 5 & 31 & 912 & 34 & 1054 \\
\hline Total & - & 90 & 1087 & 91 & 1216 \\
\hline \multirow{5}{*}{ Castellón } & 1 & 8 & 1 & 8 & 1 \\
\hline & 2 & 20 & 15 & 12 & 7 \\
\hline & 3 & 11 & 28 & 14 & 29 \\
\hline & 4 & 13 & 75 & 16 & 99 \\
\hline & 5 & 7 & 118 & 11 & 216 \\
\hline Total & - & 59 & 237 & 61 & 352 \\
\hline \multirow{5}{*}{ Valencia } & 1 & 27 & 3 & 22 & 2 \\
\hline & 2 & 25 & 17 & 23 & 15 \\
\hline & 3 & 27 & 57 & 28 & 61 \\
\hline & 4 & 22 & 126 & 23 & 134 \\
\hline & 5 & 18 & 267 & 24 & 452 \\
\hline Total & - & 119 & 470 & 120 & 664 \\
\hline TOTAL & & 268 & 1794 & 272 & 2232 \\
\hline
\end{tabular}

ties). The resulting hierarchy was as expected and therefore it is demonstrated that the methodology used is valid at least in comparative terms. Furthermore, the knowledge we have about the evolution of the real estate market also validates the trends noted by the variation of the results between 2005 and 2009.

To interpret these results, it must be remembered that the methodology has been framed within the territorial scope of the Valencian Community. It is intended to raise a generalist modelling tool, for comparing different levels of condition that could be easily repeated and will serve as an indicator for more accurate models. A first approximation to the problem under study requires territorial or regional planning at a specific scale. Furthermore, a local scale will be used for the definition of specific measures and the value of residential buildings in detail. Basically, what we want are results for comparing the level of risk in different administrative domains. Thus, the primary aim is to manage and prioritize investment in research to more precise scales, allowing the adoption of concrete measures. Therefore, the result obtained is useful in the management of the regional and local administrations.

The scale used corresponds to territorial or regional planning, which in this case is defined as macro-scale. According to this scale, damage assessment has been conducted at the municipal administrative unit level (Messner and Meyer, 2006). The methodological development and the scale used justify a low level of accuracy in the results (in thousands of euros) and the amount of resources required per unit area and the input data required.

The availability of more accurate data, such as land use according to SIOSE (data $1: 25000$ ) does not undermine the results, but makes possible a higher level of accuracy in regard to buildings susceptible to damage.

All the used data come from official public sources. These data have been developed by different administrations at the national and regional level, and they give particular strength to the methodology proposed, ensuring repeatability and consistency of the calculations of the results. The landslide hazard mapping prepared by the Regional Administration at $1: 50000$ (COPUT) is perhaps the more limited data source, with greater uncertainty and therefore the one that defines the scale of the work.

Obviously, the working scale of $1: 50000$ is not appropriate for detailed studies, but our aim has been to obtain a primary tool for risk management at LAU2 level, and we believe that this scale is enough for our initial purposes. The main weakness of our source map is the lack of characterization of each cartography slide (probability, type, estimated depth, etc.). We are convinced that to improve the quality of results it is necessary to improve and to complete the source of data inputs and begin to make a landslide inventory database. Unfortunately, that work is beyond the scope of our limited work 
team - instead it should be guided and carried out by the Local Administration.

The methodology developed for the assessment of buildings is one of the processes that gives added value to this research. Based on the market value obtained from the FBBVA Report (Albert and Uriel, 2012), we have disaggregated local units into smaller units, associated with the classification type of residential buildings defined by the SIOSE land cover model. This methodology allows us to estimate the value of dwellings associated with SIOSE polygons, more accurately than the average given by the FBBVA Report. To perform the disaggregation, we have used official and public sources of information (see Fig. 2). All these sources have allowed to adjust the value of the building for each polygon SIOSE, adding again at municipal level the value of the dwellings affected by landslide hazard. This methodology ensures the homogeneity of the generated data and an ease of updating in the future.

A limitation that we have encountered is the absolute lack of a regional database on the valuation of vulnerability of buildings to landslides. This fact is a well-known and widespread problem, and it hindered application of the intensity/degree of loss curves methodology. This situation has been resolved by using a simple damage matrix with theoretical values, as shown in Table 9. Our calculation of the loss in market value of the buildings is an estimation of the direct and tangible damage, that does not necessarily require determination of the other ones (indirect or intangible). The purpose of this work is to establish a methodology to support decision making, so we do not need a detailed analysis of damages and specific measures to minimize them.

In fact, the damage value obtained by municipality is not an absolute value, due to the uncertainty it may have. Nevertheless, the comparison between values of different administrative units is one of the greatest interests of this paper. Therefore, these values were reclassified by intervals at different risk levels (low, medium and high), in order to establish a clear hierarchy of municipalities.

\section{Conclusions}

This is a novel work in the ambit of risk assessment in that it proposes a direct general assessment method for geolocalized dwellings capable of being unrestrictedly applied to any area in Spain. Detailed land use maps, such as those offered by the SIOSE model, are essential as a dasymetric variable for the breakdown of the original data.

A landslide risk assessment model was designed to use easily available official data compiled by public organizations, which also happens to be the only available data source for the total area of this field. It has to be admitted that landslide risk maps need to be updated and improved - both conceptually to clearly include the probabilistic variable, and as regards questions of scale - though at the present time we can see little likelihood of this being carried out.

As we now have the entire automated assessment process available in Python routines in ESRI ArcGIS 10.1, this will make it possible to implement any update or modification with ease. Our next objective therefore is to carry out a similar assessment of dwellings for the whole of Spain, including the entire affected population according to the population grid available for 2005 and 2010 (Goerlich and Cantarino, 2013). Furthermore, the process has been designed in such a way that it can be applied to other geographical areas, provided the appropriate hazard maps are available.

The results obtained on landslide risk assessment in the Valencia Community make it possible to compare different zones; they can also be used as the basis for detailed studies, and offer local authorities objective indicators to help in making decisions on advisable actions. However, bearing in mind the scale of the work, the area of the analysed territory, the method used and the input data, these results should not be assumed to be definitive, but rather as a first step in the right direction. Nor, of course, should they be allowed to alarm local populations by assigning quantitative values to specific areas.

From the land planning perspective, the results obtained can be considered satisfactory as a response to the rational use of residential land in municipal districts or even larger areas. Indeed, this work has created a method that accurately uses local data sources to assist municipal authorities in taking the appropriate decisions according to the landslide risk evaluated. In fact, specifying the appropriate measures to be adopted could be regarded as an important new line of study.

Acknowledgements. The authors are grateful to the BBVA Foundation and to Carlos Albert and Ezequiel Uriel, the authors of the report on the Spanish housing stock, for making available to them original data from their report. The translation of this paper was funded by the University Polytechnic of Valencia (Spain). The authors also acknowledge valuable comments received from the anonymous reviewers.

Edited by: T. Glade

Reviewed by: four anonymous referees

\section{References}

Alexander, D.: Natural Disasters. University College London Press, London, 632 pp., 1993

Alexander, D.: Confronting Catastrophe, New York: Oxford University Press, 288 pp., 2000.

Albert, C. and Uriel, E.: El stock de capital de viviendas (1990-2010) y en otras construcciones (19902009) en España, y su distribución territorial, Fundación BBVA, available at: http://www.fbbva.es/TLFU/dat/ elstockdecapitalenviviendas(1990-2010)_web.pdf (last access: January 2014), 2012. 
Bonachea, J.:Desarrollo, aplicación y validación de procedimientos y modelos para la evaluación de amenazas, vulnerabilidad y riesgo debidos a procesos geomorfológicos, $\mathrm{Ph} . \mathrm{D}$. Thesis, University of Cantabria (Spain), available at: http://www.tdx.cat/ handle/10803/10610 (last access: January 2014), 2006.

Brabb, E. E.: Innovative approaches to landslide hazard and risk mapping, Proceedings of the Fourth International Symposium on Landslides, Canadian Geotechnical Society, Toronto, Canada, 1, 307-323, 1984.

Catani, F., Casagli, N., Ermini, L., Righini, G., and Menduni, G.: Landslide hazard and risk mapping at catchment scale in the Arno River basin, Landslides, 2, 329-342, doi:10.1007/s10346005-0021-0, 2005.

COPUT (Conselleria d'Obres Publiques, Urbanisme i Transports): Litología, aprovechamiento de rocas industriales y riesgo de deslizamiento en la Comunidad Valenciana, Gobierno Valenciano, 1998

COPUT (Conselleria d'Obres Publiques, Urbanisme i Transports): Orden de 15 febrero de 2000, por la que se amplían las cartografías temáticas declaradas de necesaria observancia en la redacción de los planes urbanísticos o territoriales que se formulen en la Comunidad Valenciana, [2000/F1221], Gobierno Valenciano (DOCV núm. 3691, 18.02.2000), 2000.

Corominas, J.: El clima y sus consecuencias sobre la actividad de los movimientos de ladera en España, Rev. C \& G., 20, 89-113, 2006.

Corominas, J., Moya, J., Ledesma, A., Gili, J. A., Lloret, A., and Ruis, J. (Eds.): New technologies for landslide hazard assessment and management in Europe (NEWTECH), Contract ENVCT96-0248, final report, European Commission: Environment Programme, 1998.

Corominas, J., Ayala, F. J., Cendrero, A., Chacón, J., Díaz de Terán J. R., González, A., Moya, J., and Vilaplana, J. M. : Riesgos de inestabilidad de laderas, in: Evaluación Preliminar de los Impactos en España por Efecto del Cambio Climático, 549-579, MAGRAMA, 2005.

Corominas, J., van Westen, C., Frattini, P., Cascini, L., Malet, J. P., Fotopoulou, S., Catani, F., Van Den Eeckhaut, M., Mavrouli, O., Agliardi, F., Pitilakis, K., Winter, M. G., Pastor, M., Ferlisi, S., Tofani, V., Hervás, J., and Smith, J. T.: Recommendations for the quantitative analysis of landslide risk, B. Eng. Geol. Environ., 73, 209-263, doi:10.1007/s10064-013-0538-8, 2014.

Dai, F. C., Lee, C. F., and Ngai, Y. Y.: Landslide risk assessment and management: an overview, Eng. Geol., 64, 65-87, 2002.

EEA (European Environmental Agency): Mapping the impacts of natural hazards and technological accidents in Europe, EEA Technical Report, no. 13, 2010.

ESPON: The Spatial Effects and Management of Natural and Technological Hazards in Europe - ESPON 1.3.1, 2006.

Fell, R.: Landslide risk assessment and acceptable risk, Can. Geotech. J., 31, 261-272, 1994.

Fell, R., Ho, K. K. S., Lacasse, S., and Leroi, E.: A framework for landslide risk assessment and management, in: Landslide Risk Management, edited by: Hungr, O., Fell, R., Couture, R., and Eberhardt, E., Taylor and Francis, London, 3-26, 2005.

Fell, R., Corominas, J., Bonnard, Ch., Cascini, L., Leroi, E., and Savage, W. Z.: On behalf of the TCJoint Technical Committee on Landslides and Engineered Slopes, Guidelines for landslide susceptibility, hazard and risk zoning for land use planning, Eng. Geol., 102, 85-98, 2008.

Glade, T.: Vulnerability assessment in landslide risk analysis, Die Erde, 134, 121-138, 2003.

Glade T., Anderson M., and Crozier M. J.: Landslide Hazard and Risk, John Wiley \& Sons, Ltd, Chichester, England, 802 pp., 2005.

Goerlich, F. J. and Cantarino, I.: A population density grid for Spain, Int. J. GIS, 27, 2247-2263, doi:10.1080/13658816.2013.799283, 2013.

IGN (National Geographic Institute): Land Cover and Use Information System of Spain (SIOSE) Technical document Version 2.0, Madrid, 2010.

IUGS Working group on landslides-Committee on Risk Assessment, in: Quantitative risk assessment for slopes and landslides, edited by: Cruden, D. and Fell, R., Landslide risk assessment, Balkema, Rotterdam, 3-12, 1997.

IVE (Instituto Valenciano de la Edificación): Coste Unitario de Ejecución, Edificación Residencial, Gobierno Valenciano, available at: http://www.five.es/inicio/economia/457.html (last access: November 2013), 2012.

Kleist, L., Thieken, A. H., Köhler, P., Müller, M., Seifert, I., Borst, D., and Werner, U.: Estimation of the regional stock of residential buildings as a basis for a comparative risk assessment in Germany, Nat. Hazards Earth Syst. Sci., 6, 541-552, doi:10.5194/nhess-6-541-2006, 2006.

Lee, E. M. and Jones, D. K. C.: Landslide risk assessment, Thomas Telford Books, London, 454 pp., 2004.

Leone, F.: Concept de vulnérabilité appliqué à l'évaluation des risques générés par les phénomènes de mouvements de terrain, $\mathrm{Ph}$. D. Thesis, Joseph Fourier University, Grenoble I (France), 1996a.

Leone, F., Asté, J. P. and Leroi, E.: L'évaluation de la vulnérabilité aux mouvements de terrains : pour une meilleure quantification du risqué, Revue de géographie alpine, 1996, Tome 84, 1, 35-46, $1996 b$.

Leroi, E.: Landslide hazard-Risk maps at different scales: Objectives, tools and developments, in: Landslides-Glissements de terrain, edited by: Senneset, K., Trondheim, Norway, Balkema, Rotterdam, 35-51, 1996.

Li, Z., Nadim, F., Huang, H., Uzielli, M., and Lacasse, S. :Quantitative vulnerability estimation for scenario-based landslide hazards, Landslides, 7, 125-134, doi 10.1007/s10346-009-0190-3, 2010 .

Luino, F., Biddoccu, M., Cirio, C. G., Agangi, A., Giulietto, W., Godone, F., and Nigrelli, G.: Application of a model for the evaluation of flood damage, GeoInformatica, Springer Ed, 13, 339353, 2009.

Messner, F. and Meyer, V.: Flood damage, vulnerability and risk perception - challenges for flood damage research, Flood Risk Management: Hazards, Vulnerability and Mitigation Measures, NATO Science Series, 67, 149-167, 2006.

Palencia, J. S. and Gielen, E.: La importancia de la vulnerabilidad frente a inundaciones como criterio de buen gobierno en materia de ordenación territorial, VI Congreso Internacional de Ordenación del Territorio, Pamplona (Spain), 81-95, 2010.

Papathoma-Köhle, M., Kappes, M., Keiler, M., and Glade, T.: Physical vulnerability assessment for alpine hazards: state of the art and future needs, Nat. Hazards, 58, 645-681, 2011. 
Papathoma-Köhle, M., Keiler, M., Totschnig, R., and Glade, T.: Improvement of vulnerability curves using data from extreme events: a debris flow event in South Tyrol, Nat. Hazards, 64, 2083-2105, 2012.

UN-ISDR: Terminology on disaster risk reductions, International Strategy for Disaster Reduction, Geneva, available at: http: //www.unisdr.org/?les/7817_UNISDRTerminologyEnglish.pdf (last access: October 2013), 2009.

UNDRO: Natural Disasters and Vulnerability Analysis, Report of Expert Group Meeting, Genève, 1979.

UNDRO: Mitigation Natural Disaster: Phenomena, Effects and Action - A manual for Policy makers and Planners, Geneva, Office of the UN Disaster Relief Coordinator, 1991.

Valcárcel, N.: Comparison and parameterization between SIOSE and CLC, 6th EAGLE meeting and Joint Meeting EAGLE-Geoland2, June 2011, Málaga (Spain), avalaible at: http://sia.eionet.europa.eu/EAGLE/EAGLE_6thMeeting_g2_ Malaga/03_CLC-Attribution_GHS_Homework.pdf (last access: January 2014), 2011.
Van Den Eeckhaut, M. and Hervas, J.: State of the art of national landslide databases in Europe and their potential for assessing landslide susceptibility, hazard and risk, Geomorphology, 139140, 545-558, doi:10.1016/j.geomorph.2011.12.006, 2012.

Van Westen, C. J., Van Asch, T. W. J., and Soeters, R.: Landslide hazard and risk zonation; why is it still so difficult?, B. Eng. Geol. Environ., 65, 167-184, 2005.

Varnes, D. J.: Landslide hazard zonation: a review of principles and practice, UNESCO, Paris, 63 pp., 1984.

Wright, J. K.: A method of mapping densities of population with Cape Cod as an example, Geographical Review, 26, 103-110, 1936. 